\title{
Peningkatan Pertumbuhan dan Hasil Sawi Hijau (Brassica juncea, L.) Dengan Pemberian Bokashi Eceng Gondok (Eichornoa crassipes)
}

\author{
Herlina Kurniawati dan Kristian Very \\ Fakultas Pertanian Universitas Kapuas Sintang \\ email: herlina_kurniawati@yahoo.com
}

\begin{abstract}
Abstrak: Pengunaan bahan organik sebagai pupuk memberikan keuntungan karena bahan-bahan organik akan mengaktifkan kehidupan mikroorganisme tanah dan menambah bahan organik tanah sehingga berpengaruh terhadap struktur tanah. Penelitian ini bertujuan untuk: 1) mengetahui pengaruh bokashi eceng gondok terhadap pertumbuhan dan hasil tanaman sawi hijau pada tanah PMK; 2) mengetahui dosis bokashi yang tepat terhadap pertumbuhan dan hasil tanaman sawi hijau pada tanah PMK. Ruang lingkup penelitian ini terdiri dari bokashi sebagai variabel bebas dan jumlah daun dan berat segar tanaman sebagai variabel terikat. Penelitian ini dilakukan dengan metode eksperimen lapangan. Rancangan lingkungan yang digunakan dengan pola rancangan acak kelompok (RAK). Faktor perlakuan dalam penelitian ini adalah pemberian bokashi (B) yang terdiri dari 6 taraf perlakuan dengan 4 kali pengulangan. Adapun taraf perlakuan bokashi terdiri dari: $\mathrm{B}_{0}=$ kontrol (tidak diberi bokashi), $\mathrm{B}_{1}=1 \mathrm{~kg}$ bokashi per $\mathrm{m}^{2}, \mathrm{~B}_{2}=2 \mathrm{~kg}$ bokashi per $\mathrm{m}^{2}, \mathrm{~B}_{3}=3 \mathrm{~kg}$ bokashi per $\mathrm{m}^{2}, \mathrm{~B}_{4}=4 \mathrm{~kg}$ bokashi per $\mathrm{m}^{2}, \mathrm{~B}_{5}=5 \mathrm{~kg}$ bokashi per $\mathrm{m}^{2}$. Data dianalisa dengan sidik ragam pada taraf 0,05 dan 0,01 , selanjutnya data diuji dengan uji BNJ. Hasil penelitian menunjukkan bahwa bokashi eceng gondok berpengaruh nyata terhadap jumlah daun dan berat segar pada tanaman sawi hijau. Melalui Uji BNJ diketahui bahwa pemberian $5 \mathrm{~kg}$ bokashi eceng gondok menghasilkan rata-rata 11,25 helai daun dan rata-rata berat segar pertanaman 23,90 gram.
\end{abstract}

Kata Kunci: Bokashi, PMK, Sawi Hijau, Hasil

\section{PENDAHULUAN}

Sawi hijau (Brassica juncea,

L.) merupakan tanaman semusim yang mengandung nilai gizi seperti protein 1,2 g, lemak 0,3 g, karbohidrat 4,0 g, vitamin A 0,1, vitamin B 3,0 dan vitamin C 2,0. Selain itu sayuran sawi hijau kaya akan serat yang berguna untuk kesehatan pencernaan. Di antara tanaman sayur-sayuran yang mudah dibudidayakan seperti tanaman sawi hijau, karena sawi hijau ini sangat mudah dikembangkan dan banyak kalangan yang menyukai dan memanfaatkannya, selain itu juga tanaman ini berfungsi sebagai obat untuk menyembuhkan berbagai penyakit seperti hipertensi, serta mempercepat penyembuhan luka. Selain itu kebutuhan sayuran semakin meningkat dari waktu ke 
Peningkatan Pertumbuhan dan Hasil Sawi Hijau (Brassica juncea, L.) Dengan Pemberian Bokashi Eceng Gondok (Eichornoa crassipes)

waktu, hal ini di sebabkan semakin bertambahnya anggota dalam keluarga dan berkembangnya pengetahuan masyarakat akan kebutuhan gizi seimbang, sehingga kesadaran untuk mengkonsumsi sayuran sangat penting untuk kesehatan. (Rizky 2015).

Menurut Badan Pusat Statistik (2016) Kabupaten Sintang, produksi sawi hijau pada tahun 2015 sampai 2016 tidak mengalami peningkatan yaitu 1,61 ton/ha. Hal tersebut karena kurangnya upaya untuk meningkatkan produksi sawi hijau. Salah satu penyebab rendahnya produksi tanaman sawi hijau yang rendah yaitu miskinnya unsur hara didalam tanah terutama di Daerah Kalimantan Barat Kabupaten Sintang yang sebagian besar tanahnya terdiri dari tanah podsolik merah kuning yang miskin akan unsur haranya. Menurut Badan Pusat Statistik Kabupaten Sintang (2016), tanah podsolik merah kuning mencapai 0,93 juta Ha. Salah satu upaya untuk meningkatkan hasil produksi sawi hijau yaitu dengan menambahkan unsur hara pada tanah. Untuk memperbaiki sifat fisik dan kimia tanah serta unsur hara yang kurang pada tanah, dapat dilakukan dengan pemberian bahan organik berupa bokashi eceng gondok. Bahan organik dapat menghasilkan asam-asam organik yang dapat meningkatkan $\mathrm{pH}$ tanah. Selain itu, pemberian bahan organik dapat meningkatkan kadar C-organik tanah.

C-Organik sebagai sumber makanan mikroorganisme pengurai dapat meningkatkan aktivitasnya. Sehingga proses dekomposisi dan reaksi-reaksi pembentukan unsur hara N, P, K dapat meningkat. Penambahan bahan organik dapat mempertahankan ketersediaan air serta memperbaiki aerasi tanah.

Eceng gondok sebagai gulma air memiliki produktivitas yang sangat tinggi. Peningkatan populasinya yang tinggi ini dapat menyebabkan beberapa permasalahan perairan terutama pada ekosistem air. Pemanfaatan eceng gondok sebagai bokashi menjadi salah satu cara pengendalian populasinya.

Penelitian ini bertujuan untuk a) mengetahui pengaruh bokashi 
Peningkatan Pertumbuhan dan Hasil Sawi Hijau (Brassica juncea, L.) Dengan Pemberian Bokashi Eceng Gondok (Eichornoa crassipes)

eceng gondok terhadap pertumbuhan dan hasil sawi hijau pada tanah PMK; b) mengetahui dosis bokashi eceng gondok yang akan menghasilkan pertumbuhan dan hasil tanaman sawi hijau terbaik pada tanah PMK.

\section{METODOLOGI PENELITIAN}

\section{Metode Penelitian}

Penelitian ini dilakukan dengan metode eksperimen lapangan pola rancangan acak kelompok (RAK). Terdiri dari 6 taraf perlakuan dengan 4 kali ulangan yaitu: $\mathrm{B}_{0}=$ Tanpa bokashi eceng gondok, $\mathrm{B}_{1}=1$ $\mathrm{kg}$ bokashi eceng gondok $/ \mathrm{m}^{2}, \mathrm{~B}_{2}=2$ $\mathrm{kg}$ bokashi eceng gondok $/ \mathrm{m}^{2}, \mathrm{~B}_{3}=3$ $\mathrm{kg}$ bokashi eceng gondok $/ \mathrm{m}^{2}, \mathrm{~B}_{4}=4$ $\mathrm{kg}$ bokashi eceng gondok $/ \mathrm{m}^{2}, \mathrm{~B}_{5}=5$ $\mathrm{kg}$ bokashi eceng gondok $/ \mathrm{m}^{2}$.

\section{Satuan Percobaan Dan Satuan}

\section{Pengamatan}

Satuan percobaan pada
penelitian ini adalah 6 taraf
perlakuan bokashi eceng gondok $\mathrm{x}$
16 tanaman dalam tiap petak percobaan $\mathrm{x} \quad 4$ ulangan $=384$ tanaman, dalam tiap petak percobaan diambil 4 tanaman $\times 6$ taraf perlakuan x 4 ulangan $=96$ tanaman pengamatan.

\section{Bahan dan Alat Penelitian}

Bahan yang digunakan dalam penelitian adalah benih sawi hijau sebagai benih percobaan, eceng gondok sebagai bahan bokashi, kotoran sapi sebagai campuran pembuatan bokashi, air sebagai campuran dalam bokashi, EM4 untuk membantu penguraian bokashi, gula pasir sebagai makanan mikroba.

Alat yang digunakan dalam penelitian adalah parang untuk membersihkan areal lahan percobaan, cangkul untuk mengolah tanah percobaan, gembor untuk menyiram tanaman percobaan, mini sprayer untuk menyemprot hama tanaman, triplek dengan ketebalan $3 \mathrm{~mm}$ digunakan untuk membuat kode perlakuan pada masing-masing petak percobaan, timbangan duduk untuk menimbang hasil panen, kamera digital untuk membuat dokumentasi, ATK untuk mencatat setiap hasil percobaan, meteran untuk mengukur tanaman percobaan, daun pisang untuk membuat naungan, terpal untuk alas pembuatan bokashi eceng gondok. 
Peningkatan Pertumbuhan dan Hasil Sawi Hijau (Brassica juncea, L.) Dengan Pemberian Bokashi Eceng Gondok (Eichornoa crassipes)

\section{Waktu dan tempat penelitian}

Penelitian ini dilaksanakan di

Desa Riam Kijang Kecamatan

Sungai Tebelian Kabupaten Sintang.

Penelitian dimulai pada bulan

Desember 2018 sampai Maret 2019.

\section{HASIL DAN PEMBAHASAN}

\section{Hasil Penelitian}

1. Jumlah Daun

Data pengamatan pengaruh bokashi eceng gondok terhadap ratarata jumlah daun ditampilkan dalam Tabel 1.

Tabel 1. Data Jumlah Daun

\begin{tabular}{|c|c|c|c|c|c|c|}
\hline \multirow{2}{*}{ Perlakuan } & \multicolumn{4}{|c|}{ Ulangan } & \multirow{2}{*}{ Jumlah } & \multirow{2}{*}{ Rata-rata } \\
\hline & 1 & 2 & 3 & 4 & & \\
\hline $\mathbf{B}_{0}$ & 8,00 & 8,00 & 8,25 & 8,75 & 33,00 & 8,25 \\
\hline $\mathbf{B}_{1}$ & 8,50 & 9,00 & 8,75 & 8,25 & 34,50 & 8,63 \\
\hline $\mathbf{B}_{2}$ & 9,25 & 10,00 & 9,75 & 9,25 & 38,25 & 9,56 \\
\hline $\mathbf{B}_{3}$ & 10,25 & 9,75 & 9,50 & 10,00 & 39,50 & 9,88 \\
\hline $\mathbf{B}_{4}$ & 11,25 & 10,75 & 11,00 & 10,00 & 43,00 & 10,75 \\
\hline $\mathbf{B}_{5}$ & 11,50 & 11,50 & 10,75 & 11,25 & 45,00 & 11,25 \\
\hline Jumlah & 58,75 & 59,00 & 58,00 & $\mathbf{5 7 , 5 0}$ & 233,25 & 9,72 \\
\hline
\end{tabular}

Sumber : Hasil pengamatan, 2019

Pemberian $\quad 5 \quad \mathrm{~kg}$ bokashi $\quad$ sedikit pada perlakuan $\mathrm{b}_{0}$ (kontrol) eceng gondok menghasilkan daun dengan jumlah rata-rata 8,25 daun. terbanyak dengan rata-rata 11,25 Data kemudian dianalisis dengan daun, sedangkan jumlah daun paling sidik ragam seperti yang tertera pada Tabel 2.

Tabel 2. Analisis Ragam Jumlah Daun

\begin{tabular}{|c|c|c|c|c|c|c|}
\hline \multirow{2}{*}{ SK } & \multirow{2}{*}{ DB } & \multirow{2}{*}{ JK } & \multirow{2}{*}{ KT } & \multirow{2}{*}{ F-hit } & \multicolumn{2}{|c|}{ F-tabel } \\
\hline & & & & & 0,5 & 0,1 \\
\hline Kelompok & 3 & 0,24 & 0,08 & $0,49 \mathrm{~ns}$ & 3,29 & 2,49 \\
\hline Perlakuan & 5 & 27,24 & 5,45 & $33,56 * *$ & 0,91 & 4,56 \\
\hline Galat & 15 & 2,43 & 0,16 & & & \\
\hline Jumlah & 23 & 29,91 & & $\mathbf{k k}=$ & 0,27 & \\
\hline Sumber & \multirow{2}{*}{\multicolumn{6}{|c|}{$\begin{array}{l}\text { Hasil analisis data } 2019 \\
: * * \text { berpengaruh sangat nyata pada taraf kepercayaan } 99 \% \\
\mathrm{~ns}=\text { tidak berpengaruh pada taraf kepercavaan } 95 \%\end{array}$}} \\
\hline Keterangan & & & & & & \\
\hline
\end{tabular}


Peningkatan Pertumbuhan dan Hasil Sawi Hijau (Brassica juncea, L.) Dengan Pemberian Bokashi Eceng Gondok (Eichornoa crassipes)

Hasil Uji F yang dilakukan nyata terhadap jumlah daun tanaman menunjukan bahwa pemberian sawi hijau maka dilanjutkan dengan bokashi eceng gondok berpengaruh Uji BNJ seperti pada Tabel 3.

Tabel 3. Uji BNJ Jumlah Daun

\begin{tabular}{|c|c|c|c|c|c|c|}
\hline Perlakuan & Rerata & & & Selisih & & \\
\hline $\mathbf{B}_{0}$ & $8,25 \mathrm{a}$ & & & & & \\
\hline $\mathbf{B}_{1}$ & $8,63 \mathrm{a}$ & $0,38 \mathrm{tn}$ & & & & \\
\hline $\mathbf{B}_{2}$ & $9,56 \mathrm{~b}$ & $1,31 * *$ & $0,93 * *$ & & & \\
\hline $\mathbf{B}_{3}$ & $9,88 \mathrm{~b}$ & $1,63 * *$ & $1,25 * *$ & $0,31 \mathrm{tn}$ & & \\
\hline $\mathbf{B}_{4}$ & $10,75 \mathrm{c}$ & $2,50 * *$ & $2,12 * *$ & $1,19 * *$ & $0,88 * *$ & \\
\hline $\mathbf{B}_{5}$ & $11,25 \mathrm{~d}$ & $3,00 * *$ & $2,62 * *$ & $1,69 * *$ & $1,38 * *$ & $0,50^{*}$ \\
\hline \multicolumn{7}{|c|}{$\mathrm{SE}=\mathbf{0 , 1 0}$} \\
\hline Q $0,05=$ & 4,37 & & $\mathbf{B N J}=$ & 0,44 & & \\
\hline Q $0,01=$ & 5,56 & & BNJ= & 0,56 & & \\
\hline
\end{tabular}

Sumber : Hasil analisis data, 2019

Keterangan $\quad: *$ = berbeda nyata pada taraf kepercayaan $95 \%$

$* *$ = berbeda nyata pada taraf kepercayaan $99 \%$

tn = tidak berpengaruh nyata

Nilai yang diikuti huruf yang sama memperlihatkan tidak beda nyata

Hasil Uji BNJ 2. Berat Segar Pertanaman

memperlihatkan bahwa semakin

tinggi dosis bokashi eceng gondok

Rerata pengamatan pengaruh bokashi eceng gondok terhadap berat segar tanaman sawi hijau

yang diberikan pada tanaman sawi pertanaman diperlihatkan dalam

hijau jumlah daun juga semakin baik

Tabel 4.

dengan jumlah rata-rata daun 11,25

helai per tanaman. 
Peningkatan Pertumbuhan dan Hasil Sawi Hijau (Brassica juncea, L.) Dengan Pemberian Bokashi Eceng Gondok (Eichornoa crassipes)

Tabel 4. Berat Segar Per Tanaman (g)

\begin{tabular}{|c|c|c|c|c|c|c|}
\hline \multirow{2}{*}{ Perlakuan } & \multicolumn{4}{|c|}{ Ulangan } & \multirow{2}{*}{ Jumlah } & \multirow{2}{*}{ Rata-rata } \\
\hline & 1 & 2 & 3 & 4 & & \\
\hline $\mathbf{B}_{0}$ & 18,50 & 20,75 & 20,00 & 20,75 & 80,00 & 20,00 \\
\hline $\mathbf{B}_{1}$ & 21,00 & 21,25 & 22,25 & 22,00 & 86,50 & 21,60 \\
\hline $\mathbf{B}_{2}$ & 22,75 & 23,00 & 22,25 & 22,00 & 90,00 & 22,50 \\
\hline $\mathbf{B}_{3}$ & 23,50 & 23,25 & 23,00 & 21,50 & 91,25 & 22,80 \\
\hline $\mathbf{B}_{4}$ & 22,75 & 24,25 & 23,75 & 23,50 & 94,25 & 23,60 \\
\hline $\mathbf{B}_{5}$ & 24,00 & 22,75 & 24,25 & 24,75 & 95,75 & 23,90 \\
\hline Jumlah & 132,50 & 135,25 & 135,50 & 134,50 & 537,75 & 134,40 \\
\hline
\end{tabular}

Sumber: Hasil pengamatan, 2019

Hasil pengamatan pengaruh bokashi terhadap rata-rata berat segar per tanaman memperlihatkan bahwa tanaman terberat adalah pemberian 5 $\mathrm{kg}\left(5 \mathrm{~kg}\right.$ perlakuan $\left.\mathrm{B}_{5}\right)$ dengan berat rara-rata $23,9 \mathrm{~kg}$.

Tabel 5. Analisis Ragam Berat Per Tanaman (g)

\begin{tabular}{|c|c|c|c|c|c|c|}
\hline \multirow{2}{*}{ SK } & \multirow{2}{*}{ DB } & \multirow{2}{*}{ JK } & \multirow{2}{*}{ KT } & \multirow{2}{*}{ F-hitung } & \multicolumn{2}{|c|}{ F- tabel } \\
\hline & & & & & $\mathbf{0 , 0 5}$ & 0,01 \\
\hline Kelompok & 3 & 0,92 & 0,31 & $0,47 \mathrm{~ns}$ & 3,29 & 5,42 \\
\hline Perlakuan & 5 & 41,02 & 8,20 & $12,43 * *$ & 2,90 & 4,56 \\
\hline Galat & 15 & 9,90 & 0,66 & & & \\
\hline Jumlah & 23 & 51,85 & & $\mathbf{K} \mathbf{k}=$ & 49 & \\
\hline
\end{tabular}

Sumber: Hasil analisis data, 2019

Keterangan $\quad:$ ns $=$ tidak berpengaruh pada taraf kepercayaan $95 \%$

$* *$ = pengaruh nyata pada taraf kepercayaan $99 \%$

Diketahui bahwa bokashi bokashi eceng gondok yang eceng gondok berpengaruh sangat menghasilkan berat segar tanaman nyata terhadap berat segar tanaman sawi hijau per tanaman dibuktikan sawi hijau per tanaman. Untuk mengetahui perbedaan dari perlakuan melalui Uji BNJ seperti yang diperlihatkan pada Tabel 5. 
Peningkatan Pertumbuhan dan Hasil Sawi Hijau (Brassica juncea, L.) Dengan Pemberian Bokashi Eceng Gondok (Eichornoa crassipes)

Tabel 5. Uji BNJ Berat Segar Per Tanaman (g)

\begin{tabular}{|c|c|c|c|c|c|c|}
\hline Perlakuan & Rerata & & & Selisih & & \\
\hline $\mathbf{B}_{0}$ & $20,00 \mathrm{a}$ & & & & & \\
\hline $\mathbf{B}_{1}$ & $21,63 \mathrm{~b}$ & $1,63 * *$ & & & & \\
\hline $\mathbf{B}_{2}$ & $22,50 \mathrm{c}$ & $2,50 * *$ & $0,88 \mathrm{tn}$ & & & \\
\hline $\mathbf{B}_{3}$ & $22,81 \mathrm{c}$ & $2,81 * *$ & $1,19 * *$ & $0,31 \mathrm{tn}$ & & \\
\hline $\mathbf{B}_{4}$ & $23,56 \mathrm{~cd}$ & $3,56 * *$ & $1,94 * *$ & $1,06 * *$ & 0,75 tn & \\
\hline $\mathbf{B}_{5}$ & $23,94 \mathrm{~d}$ & $3,94 * *$ & $2,31 * *$ & $1,44 * *$ & $1,13^{*}$ & 0,38 tn \\
\hline \multicolumn{7}{|c|}{$\mathrm{SE}=0,20$} \\
\hline Q $0,05=$ & 4,37 & & $\mathbf{B N J}=$ & 0,89 & & \\
\hline Q $0,01=$ & 5,56 & & $\mathbf{B N J}=$ & 1,13 & & \\
\hline
\end{tabular}

Sumber: Hasil pengamatan, 2019

Keterangan $\quad:^{*}=$ berbeda nyata pada taraf kepercayaan $95 \%$

** = berbeda nyata pada taraf kepercayaan $99 \%$

tn = tidak berpengruh nyata

Nilai yang diikuti huruf yang sama memperlihatkan tidak beda nyata

Hasil Uji BNJ pada Tabel 5 menunjukkan bahwa berat segar per tanaman mengikuti pemberian bokashi eceng gondok, dimana berat segar tanaman $\mathrm{B}_{5}$ menghasilkan berat rata-rata $23,90(\mathrm{~g})$ lebih berat dari perlakuan tanaman $\mathrm{B}_{0}, \mathrm{~B}_{1}, \mathrm{~B}_{2}$, $\mathrm{B}_{3}$, dan $\mathrm{B}_{4}$ dan begitu juga dengan perlakuan tanaman lainnya.

\section{Pembahasan}

Hasil penelitian menunjukan bahwa pemberian bokashi eceng gondok berpengaruh nyata terhadap jumlah daun dan berat segar tanaman. Pemberian bokashi eceng gondok diduga menyebabkan tanah sebagai media tumbuh tanaman sawi hijau menjadi lebih baik sehingga mendukung pertumbuhan dan hasil tanaman sawi hijau. karena bokashi eceng gondok merupakan pupuk organik. Perbaikan media tumbuh tanaman karena kandungan bokashi eceng gondok yang merupakan bahan organik akan memperbaiki sifat fisika, kimia dan biologi tanah. Yuwono (2015) menjelaskan bahwa bahan organik di dalam tanah akan menyumbang humus ke dalam tanah.

Hasil analisis laboratorium menunjukkan bahwa bokashi eceng gondok mempunyai kandungan hara $\mathrm{N}=1,34 \%, \mathrm{P}=2.361,90 \mathrm{ppm}, \mathrm{K}=$ $34,01 \mathrm{C} \mathrm{Mol} / \mathrm{Kg}$ dan $\mathrm{pH}=9,01 \mathrm{H}_{2} \mathrm{O}$. Peran terpenting dari bokashi eceng 
Peningkatan Pertumbuhan dan Hasil Sawi Hijau (Brassica juncea, L.) Dengan Pemberian Bokashi Eceng Gondok (Eichornoa crassipes)

gondok adalah sumbangan dari bahan organiknya ke dalam tanah. Hakim, dkk. (1986) menjelaskan bahwa peran bahan organik di dalam tanah adalah meningkatkan kemampuan tanah untuk menahan air, merangsang granulasi tanah, menurunkan plastisitas tanah.

Setyamidjaja

menjelaskan bahwa Nitrogen berperan penting merangsang pertumbuhan vegetatif seperti menambah tinggi tanaman dengan kandungan $\mathrm{N}=1,34 \%$ dalam bokashi eceng gondok, merangsang tumbuhnya anakan, menyusun klorofil/butir-butir hijau daun untuk fotosintesis lebih tinggi, menyusun lemak dan protein. Unsur Nitrogen membentuk asam amino sebagai kerangka protain sehingga proses pembelahan, pembesaran serta perpanjangan sel-sel dapat berjalan lancar.

Indranada

menjelaskan bahwa unsur fosfor merupakan bagian fosfor terlibat pada penangkapan energi sinar matahari yang menghantam sebuah molekul klorofil. Begitu energi sudah tersimpan dalam ADP (adenosin diphospate) atau ATP (adenosin triphoshate) dapat dipakai untuk menjalankan reaksi-reaksi yang memerlukan energi, seperti pembentukan sukrosa, tepung dan protein.

Menurut Sulisbury

kalium merupakan unsur utama yang dibutuhkan tanaman yang sangat penting perannya dalam pembentukan protein dan karbohidrat, meningkatkan resistensi terhadap hama dan penyakit tanaman serta meningkatkan kualitas biji atau buah. Peran kalium yang penting dalam tanaman diantaranya sebagai elemen penting yang bersifat higroskopis (mudah menyerap dan menahan air) unsur kalium biasanya terdapat pada stomata daun. Dengan sifatnya yang higroskopis, kalium mampu membuat persediaan air yang ada dan dibutuhkan untuk proses transpirasi, fotosintesis, absorbsi, maupun transportasi unsur hara dalam tanaman tersebut menjadi optimal.

Hasil penelitian menunjukkan bahwa rerata jumlah daun terbanyak 11,25 helai dan rerata berat segar tanaman 23,90 g, jumlah daun serta 
Peningkatan Pertumbuhan dan Hasil Sawi Hijau (Brassica juncea, L.) Dengan Pemberian Bokashi Eceng Gondok (Eichornoa crassipes)

berat segar, berpengaruh dengan pemberian bokashi eceng gondok dengan dosis $5 \mathrm{~kg} / \mathrm{m}^{2}$. Hasil penelitian tersebut menunjukkan bahwa makin tinggi dosis bokashi eceng gondok $\left(5 \quad \mathrm{~kg} / \mathrm{m}^{2}\right)$ pertumbuhan dan hasil makin meningkat. Hasil penelitian tersebut diduga pemberian bokashi eceng gondok dengan dosis $5 \mathrm{~kg} / \mathrm{m}^{2}$ telah mampu untuk memperbaiki kondisi fisik, kimia dan biologi tanah (kemampuan menahan air, granulasi tanah dan agregasi tanah, KTK tanah, penurunan kehilangan hara akibat pencucian, dan aktivitas mikro organisme). Perbaikan kondisi sifat tanah ini akan menyebabkan akar tanaman dapat tumbuh dan berkembang dengan lebih baik, yang selanjutkan akan meningkatkan kemampuan akar tanaman dalam menyerap air dan unsur hara. Peningkatan penyerapan air dan unsur hara pada akhirnya akan memperbaiki pertumbuhan dan hasil tanaman.

Dalam penelitian ini pemberian sebanyak $5 \mathrm{~kg} / \mathrm{m}^{2}$, yang merupakan dosis tertinggi pemberian bokashi eceng gondok, menunjukkan peningkatan pertumbuhan dan hasil terbaik dibandingkan dosis kurang dari $5 \mathrm{~kg} / \mathrm{m}^{2}$. Hal ini diduga karena bahan dasar bokashi yang berupa eceng gondok memiliki kandungan serat yang tinggi, sehingga bokashi eceng gondok memerlukan jumlah yang lebih banyak untuk memberikan pengaruh pada pertumbuhan dan hasil tanaman sawi. Bahan dasar bokashi akan mempengaruhi kemampuan bokashi untuk mempengaruhi pertumbuhan dan hasil tanaman. Penelitian Nurhadiah (2016) dengan menggunakan bokashi sekam padi sebanyak $2,5 \mathrm{~kg} / \mathrm{m}^{2}$ pada tanaman jagung manis menghasilkan berat tongkol kotor dan berat tongkol kupasan paling berat, serta persentase panjang tongkol kosong terhadap tongkol isi terendah. Penelitian dengan bahan dasar bokashi berbeda yang dilakukan oleh Kurniawati (2018) menunjukkan hasil penelitian yang serupa, pada penelitiannya pemberian bokashi kulit rambutan sebanyak $2 \mathrm{~kg} / \mathrm{m}^{2}$ menghasilkan tinggi tanaman dan berat segar tanaman bayam cabut tertinggi. 
Peningkatan Pertumbuhan dan Hasil Sawi Hijau (Brassica juncea, L.) Dengan Pemberian Bokashi Eceng Gondok (Eichornoa crassipes)

\section{KESIMPULAN DAN SARAN}

\section{Kesimpulan}

Dari hasil penelitian ini kesimpulan sebagai berikut:

1. Pemberian bokashi eceng gondok berpengaruh nyata terhadap jumlah daun dan berat segar pada tanaman sawi hijau, tetapi berpengaruh tidak nyata terhadap tinggi tanaman sawi hijau pada tanah PMK.

2. Pemberian dosis bokashi eceng gondok $5 \mathrm{~kg} / \mathrm{m}^{2}$ menghasilkan pertumbuhan dan hasil tanaman sawi hijau terbaik, terlihat dari jumlah daun dan berat segar.

\section{Saran}

Dari hasil penelitian ini saran sebagai berikut:

1. Bokashi eceng gondok dapat diberikan untuk meningkatkan pertumbuhan dan hasil tanaman sawi hijau pada tanah Podsolik Merah Kuning.

2. Dosis bokashi eceng gondok yang dianjurkan untuk meningkatkan hasil sawi hijau adalah $5 \mathrm{~kg} / \mathrm{m}^{2}$.

\section{DAFTAR PUSTAKA}

Derry, Suhelmyl.,Yusraz, dan Khusrizal.2014.Perubahan Kandungan N-Total, $P$ -
Tersedia Dan C-Organik Ultisol Yang Diberi Bokashi Eceng Gondok Dan Ampas Tebu. Jurnal. Aceh Utara:Fakultas Pertanian Universitas. Malikussateh. (http://repository. Unimal. ac.id/926/1/Jurnal-AgriumMaret-2014.pdf. Diakses tanggal 7 Januari 2018.

Gasperss,V.1999. Metode Perancanaan Percobaan, Bandung. Amico.

Hakim, N., Nyakpa, Y.n., Lubis, A.M., Sutopo, G.N., Saul, M.R., Diha, M.A., Go Ban Hon, dan Bailey. 1986. Dasar Dasar Ilmu Tanah, Unila Press. Lampung.

Haryanto.,Suhartini., Rahayu dan Sunarjono. 2007. Sawi dan Selada. Jakarta. Penebar Swadaya.

Indraya, Rini. 2009. Distribusi Pori Tanah Podsolik Merah Kuning Pada Berbagai Kepadatan Tanah Dan Pemberian Bahan Organik. Jurnal. Banjar baru: Fakultas Kehutanan Universitas Lambung Mangkurat. (http://download. portalgaruda. org/article. php? article $=96195$ \& val $=$ 5070. Diakses tanggal 20 Desember 2017.

Kurniawati, H. 2018. Pemanfaatan Kulit Rambutan Sebagai Bokashi Untuk Meningkatkan Pertumbuhan dan Hasil Bayam Cabut (Amaranthus 
Peningkatan Pertumbuhan dan Hasil Sawi Hijau (Brassica juncea, L.) Dengan Pemberian Bokashi Eceng Gondok (Eichornoa crassipes)

tricolor, L). Sintang. Jurnal PIPER Fakultas Pertanian Universitas Kapuas Sintang. Nomor 27 Volume 14. Hal. 357-364.

http://jurnal.unka.ac.id/index. php/piper/article/view/191.

Nurhadiah. 2016. Pengaruh Bokashi Sekam Padi Terhadap Hasil Tanaman Jagung Manis (Zea mays, L Sacharata) Pada Tanah Ultisol. Sintang. Jurnal PIPER Fakultas Pertanian Universitas Kapuas Sintang. Nomor 23 Volume 12. Hal. 147-154.

http://jurnal.unka.ac.id/index. php/piper/article/view/22.

Rukmana. 2012. Bertanam Sayuran Petsai Dan Sawi. Kanisius. Yogyakarta.

Sittadewi, Hanggari. 2007. Pengolahan Bahan Organik Eceng Gondok Menjadi Media Tumbuh Untuk Mendukung Pertanian Organik. Jurnal. Penelitian pada Pusat Teknologi Lahan
Wilayah dan Mitigasi

Bencana Badan Pengkajian dan Penerapan Teknologi. (http://www. kelair. bppt.go.id/Jt1/2007/vol83/07eceng.pdf. Diakses tanggal 20 Januari 2018.

Sunarjono, Hendro. 2016. Bertanam 36 Jenis Sayur. Penebar Swadaya. Jakarta

Yanuarismah. 2012. Pengaruh Bokashi Eceng Gondok (Eichornia Crassipes Solm) Terhadap Pertumbuhan Dan Produksi Selada (Lactuca Sativa L). Jurnal. Surakarta: Fakultas Keguruan Dan Ilmu Pendidikan Universitas Muhammadiyah.

(http://eprints. ums. ac. Id/19817/17/

Naskah_Publikasi.Pdf.

Diakses tanggal 23 Januari 2018.

Yuwono, S. 2015. Mengatasi Masalah Sampah Kota. Penebar swadaya. Jakarta. 